\title{
Efficiency of the state support for the sustainable development of the real production sector in Russia
}

\author{
Elena Vasilyeva ${ }^{1, *}$, Irina Polyakova ${ }^{1}$ \\ ${ }^{1}$ Moscow State University of Civil Engineering, Yaroslavskoe shosse, 26, Moscow, 129337, Russia
}

\begin{abstract}
Sustained and inclusive economic growth is necessary for achieving sustainable development. While economic growth and employment are important for economic security, access to financial services is an essential component of inclusive growth. In the conditions of prolonged crisis the sustainable development of the cities, as well as the real production sector in general, establishes some special requirements to the use of means of the federal budget for the state support of organizations. Reducing of some expenses is inevitable. At the same time the principle of the effective use of the budgetary funds is very urgent. During the research the indicators of activities of the enterprises with the state participation were studied including public companies, companies quoted at the exchange; credit institutions, systemically important companies; companies realizing innovative programs. The authors insist that the efficiency evaluation of the use of means of the government budget should be based on the comparison of the surplus of products from the state support and the amount of the state support for each industry. According the result of the research the conclusions about the low efficiency of the use of state support in the organizations are made in the article. According to the authors' opinion, it is connected with the actually estimate order of financing. The transition from the estimate financing to the project financing is suggested and proved in the article.
\end{abstract}

\section{Introduction}

The need to get the best possible value from spending public money will always remain a constant for those entrusted with spending decisions. The need to reduce overall spending resulting from the current financial crisis has sharpened this requirement. The continuing downward pressure on the availability of public sector finance along with the ever growing upward pressures of demand for public services will continue to further increase the need to make better use of the resources available, the challenge has never been greater. In this context it is vital that capital spending decisions are taken on the basis of highly competent professionally developed spending proposals [1].

\footnotetext{
*Corresponding author: elena.chibisova metr@mail.ru
} 
Delay of the growth rates of the Russian economy which has been observed for the last four years (since rather safe 2012) demands carrying out the balanced policy of the economic block of the government, aimed on the real production sector development. On the one hand, reducing the number of items of expenditures, i.e. the direct sequester, transfer of separate projects for more remote period are inevitable, and on the other hand investment of budgetary funds in the systemically important entities (state corporations) and institutes of development are necessary as well. The sustained and inclusive economic growth is necessary for the achieving sustainable development. While economic growth and employment are important for economic security, access to financial services is an essential component of inclusive growth.

\section{Methods}

During the research completed by the authors the following types of the companies with the state participation were studied:

- public, quoted at the exchange;

- credit;

- systematically important;

- implementing innovative programs.

The industry section of the organizations with the state participation is presented in Table 1 [2].

Table 1. Data on public joint stock companies with the share of the state participation on branches, $\%$.

\begin{tabular}{|l|c|c|}
\hline \multicolumn{1}{|c|}{ Branches } & $\begin{array}{c}\text { State } \\
\text { property }\end{array}$ & $\begin{array}{c}\text { Mixed } \\
\text { property }\end{array}$ \\
\hline Agriculture, hunting, forestry & 13.37 & 5.78 \\
\hline Fishery, fish breeding & 19.05 & 3.17 \\
\hline Mineral extraction & 2.69 & 7.53 \\
\hline Processing production & 6.90 & 9.13 \\
\hline $\begin{array}{l}\text { Production and distribution of the electric power, gas and } \\
\text { water }\end{array}$ & 5.39 & 10.34 \\
\hline Construction & 7.70 & 8.55 \\
\hline Wholesale and retail trade. repair, trucking facilities, etc. & 7.13 & 8.28 \\
\hline Hotels and restaurants & 12.87 & 6.70 \\
\hline Transport and communication & 14.84 & 11.83 \\
\hline Financial activities & 4.64 & 12.72 \\
\hline Real estate transactions, lease, services & 10.16 & 9.49 \\
\hline $\begin{array}{l}\text { Public administration and ensuring military safety, } \\
\text { compulsory social insurance }\end{array}$ & 53.70 & 9.26 \\
\hline Education & 16.67 & 13.89 \\
\hline Health care and social services & 19.40 & 13.43 \\
\hline Other municipal, social and personal services & 16.82 & 10.28 \\
\hline
\end{tabular}

According to the Center of industry economy of the Research-and-Financial Institution (RFI) at the Ministry of the Russian Federation, the share of expenses of the federal budget in 2009-2015 for institutes of development (ID) and state corporations (SC) constituted 3.53 trillion rubles the most part of funds (78\%) was allocated and used at SC and ID. $22 \%$ of the total amount or 782.12 billion rubles were used directly at the institutes of innovative development (IID).

\section{Results}


The scale of the state support can be estimated according to the share of expenses of the budget in the group of SC, ID, IID companies in GDP in 2014; it made up 1.824\%.

Despite the crisis in the national economy, the growth rates of state support have remained at the high level recently. So, the state support grew 6.5 times in 2012 in comparison with 2011. From the beginning of the crisis period its size decreased by $60 \%$ in 2013 in comparison with 2012, but in 2014 it increased 8 times in comparison with the previous period.

The share of financial investments of the state in the balance sheet total of such IID as "Fund of the WEB Innovation", "Fund of the infrastructure educational programmes", jointstock company (JSC) "Russian Investment Fund of Information Technologies", joint-stock company JSC "Russian Venture Capital Company" fluctuates from $84.5 \%$ to $94.6 \%$.

The priority item of the expenditure of budgetary funds are current expenses. At the same time if in $201166 \%$ of funds were allocated among the investments into non-current assets and only $33 \%$ were spent on current assets, since 2012 from 75 to $91 \%$ of the state support were spent on current expenses. The structure of the expenditure of budgetary funds in 2011-2014 is presented in fig. 1. Such a use of the public funds cannot be found reasonable.

The fact that many leading systemically important organizations do not publish their accounting records of the data on the received government assistance complicates the efficiency evaluation of the use of funds. This list includes: JSC "United Aircraft Corporation", JSC "DEFENCE INDUSTRY United Industrial Corporation", JSC "AvtoVAZ", JSC "Almaz-Antey Air Defence Concern", JSC "Concern Vega", JSC "Moscow Institute of Heating Engineering Corporation', JSC "Tactical Missile Armament Corporation", JSC "Garrison", JSC "Informational sputnik systems after acad. M. F. Reshetnev", JSC "S.P. Korolev Energy-and-Space Corporation", JSC "Gazpromneft", JSC "Gazprom", JSC "Zarubezhneft", JSC "Rosneft Oil Company", JSC "Crystal Production Association", JSC "Inter RAO EES", JSC "RJSC Energy Systems of the East", JSC "Federal Hydrogeneration Company RusHydro", JSC "Transneft Joint-stock company".

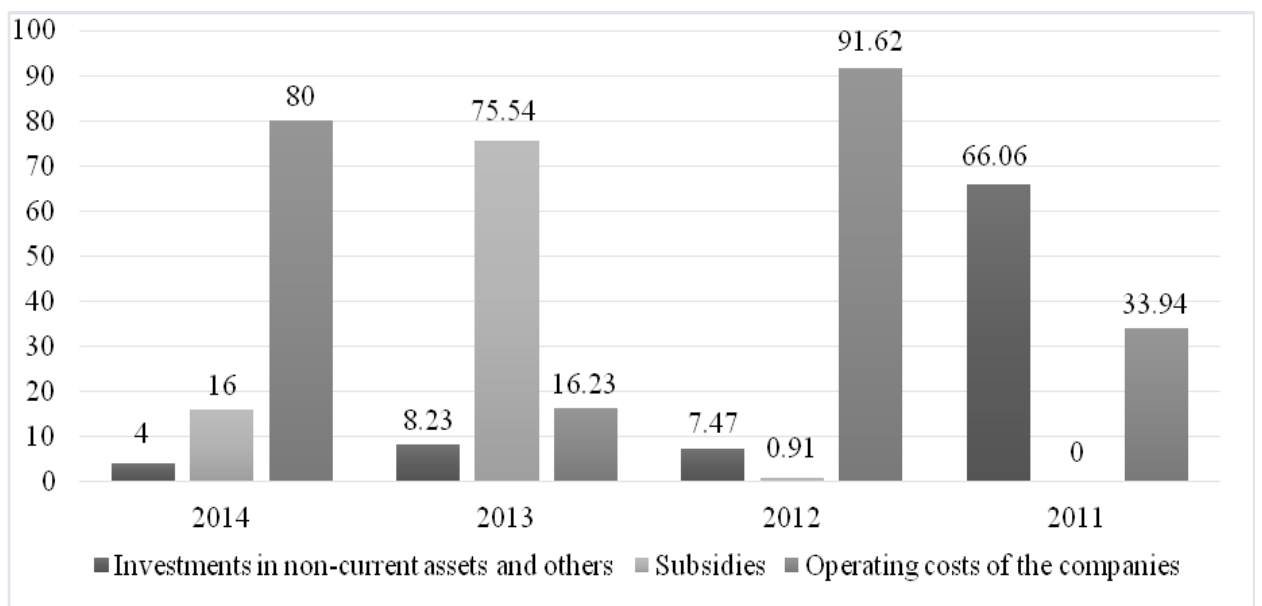

Fig. 1. Structure of the expenditure of budgetary funds in 2011-2014, \%.

The level of key economic indicators of the companies, which are realizing the programmes of innovative development does not cause too much optimism. (Table 2).

Table 2. Growth rates of the key indicators in $2014, \%$ (the basic indicator is $100 \%$ ). 


\begin{tabular}{|c|c|}
\hline Labour productivity & 112.18 \\
\hline Value added & 98.14 \\
\hline Results of the research and developments & 119.6 \\
\hline Dividends paid & 119.0 \\
\hline Prime cost & 108.56 \\
\hline Average wage/salary & 114.05 \\
\hline State support & 800.16 \\
\hline Assets & 119.44 \\
\hline Revenue & 108.56 \\
\hline Intangible assets & 174.5 \\
\hline
\end{tabular}

According to the data of Table 2, the growth of the state support during 20148 times did not provide the adequate growth of the key indicators of organization activity, such as revenue and labor productivity.

As for disaggregation of the average salary, 28 companies using the state support do not disclose such data. In the companies presenting data on the average salary, its level fluctuates from 28.27 thousand rubles in JSC "AvtoVAZ" to 249 thousand rubles in JSC "United Shipbuilding Corporation" (Figure 2).

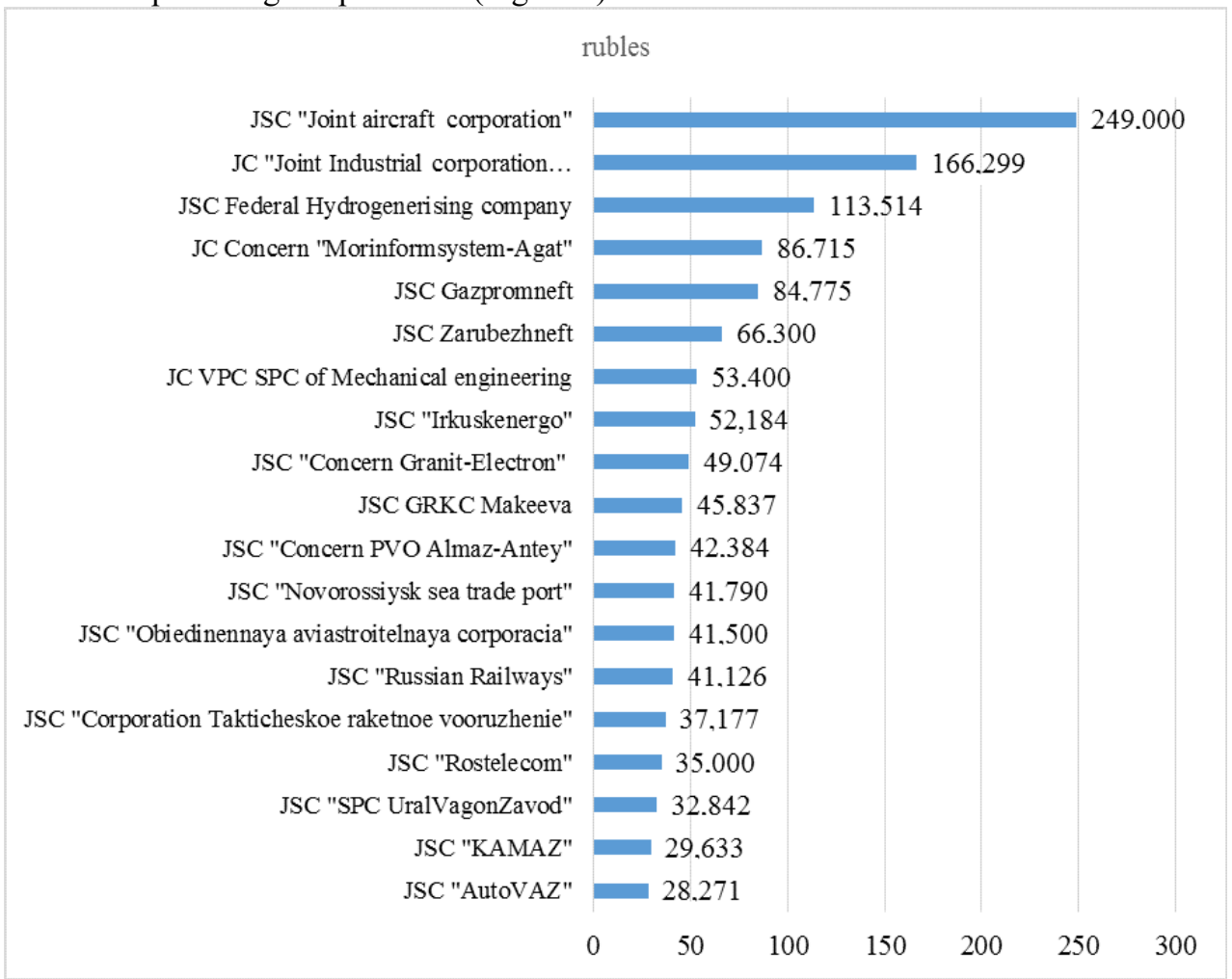

Fig. 2. The average salary in the organizations, rubles.

Such differentiation in wages and salaries has no direct link with the results of activities.

It is possible to consider the budget return of the dividend policy only in the industries concerned with production and primary conversion of raw materials (budget return of the dividend policy is determined as the amount of the added dividends, divided by the value of the state property share cost, multiplied by $100 \%$ ).

So, during the period 2009-2014 1 ruble of the state investments in the authorized capital of joint-stock companies gained the following dividends in different industries: production and preprocessing of raw materials - 3.10 rubles; financial intermediation - 
0.08 ; transport and communication -0.04 ; power industry -0.01 , aircraft industry -0.001 . Other industries have no payment for dividends in the period.

We should especially consider the problems of the banking sector, as these are the problems which aggravate difficulties in the real production sector during the crisis.

For the first ten banks according the amount of their net profit (Sberbank, Alfa-Bank, VTB-24, Raiffeisenbank, Gazprombank, FC Otkrytiye, National Clearing Centre, Bank of Russia, Rosbank) the decrease in this indicator has been observed since 2012.

Moreover, in 2015 for 802 banks the general amount of net loss made up 40.75 billion rubles. The largest depth of the fall was observed at such systemically important banks as Alfa-Bank, Rosselkhozbank, Bank of Moscow (which existed at that time). In these banks low growth rates of highly liquid means in 2015 were observed. Moreover, in Sberbank, Bank of Moscow. VTB 24, Otkrytiye Bank, Raiffeisenbank the fall of growth rates of highly liquid means was observed. Deterioration of the situation of affairs in such systemically important banks also requires state support from the in a straight line and the mediated form.

During the analyzed period the balances in cash (absolutely quick assets) in the systemically important organizations decreased too (Figure 3).

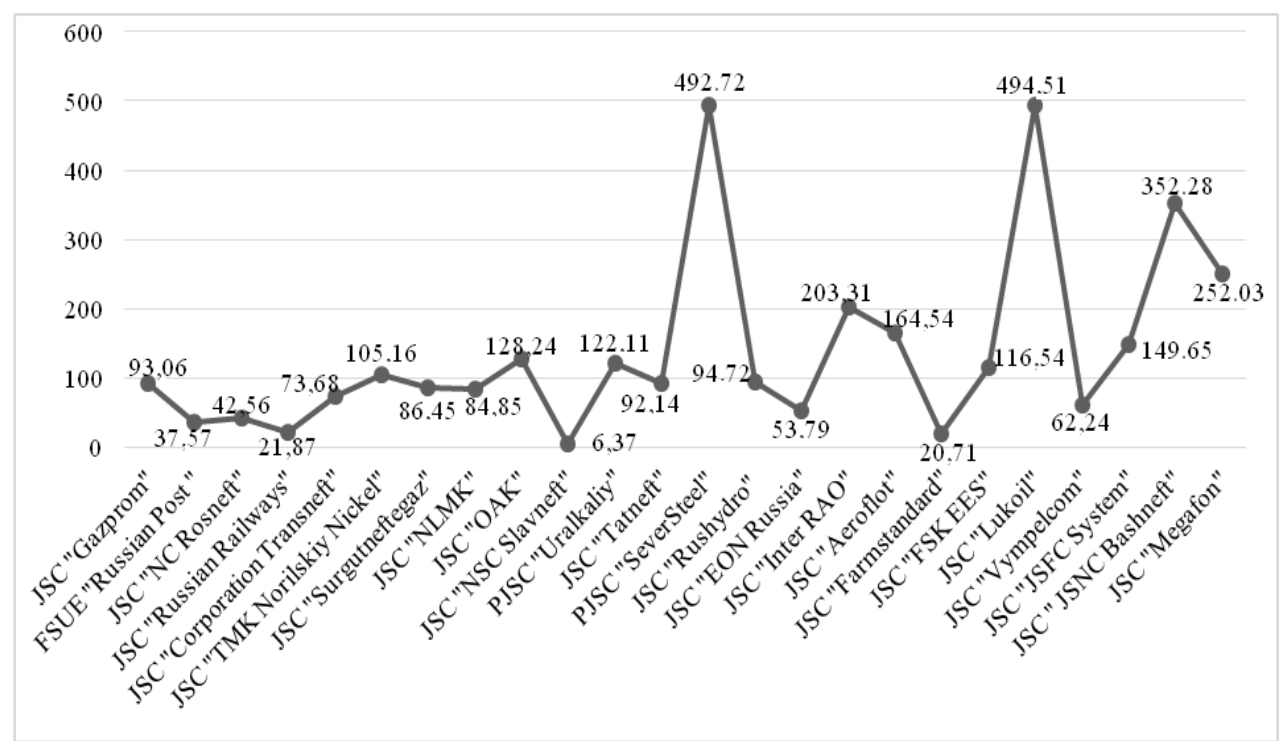

Fig. 3. Monetary assets growth rates at the systematically important Russian enterprises in 2014, \%.

While in 2008 (recession year) 80 organizations suffered the decrease in the amount of money by $50 \%$, then in 201450 organizations had such a decrease.

It is necessary to fulfil the comparison of the surplus of products from the state support with amount of the state support in industries (Table 3).

Table 3. Efficiency of support of the industries supervised by the Ministry of industry and trade of Russia in 2014.

\begin{tabular}{|c|c|c|c|c|c|c|}
\hline $\begin{array}{c}\text { Branch of } \\
\text { industry }\end{array}$ & $\begin{array}{c}\text { Volume } \\
\text { of state } \\
\text { support, } \\
\text { billions } \\
\text { of rubles. } \\
\text { GP }\end{array}$ & $\begin{array}{c}\text { Expenses, } \\
\text { billions } \\
\text { of rubles. } \\
Z\end{array}$ & $\begin{array}{c}\text { Profit. } \\
\text { billions } \\
\text { of } \\
\text { rubles. } \\
\text { P }\end{array}$ & $\begin{array}{c}\text { Gross } \\
\text { output } \\
\text { billions } \\
\text { of rubles. } \\
\text { VP }\end{array}$ & $\begin{array}{c}\text { Production } \\
\text { gain caused } \\
\text { by state } \\
\text { support, } \\
\text { billions of } \\
\text { rubles. } \\
\text { VP }+\mathrm{GP}+\mathrm{Z}\end{array}$ & $\begin{array}{c}\text { State } \\
\text { support } \\
\text { effectiveness } \\
\mathrm{E}\end{array}$ \\
\hline
\end{tabular}




\begin{tabular}{|c|c|c|c|c|c|c|}
\hline $\begin{array}{c}\text { Motor-car } \\
\text { industry }\end{array}$ & 99.25 & $1,655.4$ & 30 & $1,685.4$ & 101.1 & 1.02 \\
\hline $\begin{array}{c}\text { Machine-tool } \\
\text { construction }\end{array}$ & 2.27 & 2,617 & 98 & 2,715 & 2.4 & 1.04 \\
\hline $\begin{array}{c}\text { Defense industry } \\
\text { complex }\end{array}$ & 7.94 & 983 & 50 & 1,033 & 8.3 & 1.05 \\
\hline $\begin{array}{c}\text { Transport } \\
\text { mechanical } \\
\text { engineering }\end{array}$ & 7.32 & $2,939.5$ & -14.5 & 2,925 & 7.3 & 0.10 \\
\hline $\begin{array}{c}\text { Timber } \\
\text { processing } \\
\text { complex }\end{array}$ & 0.73 & 863.2 & -12.2 & 851 & 0.7 & 0.99 \\
\hline Light industry & 1.53 & 267.3 & 19.2 & 286.5 & 1.6 & 1.07 \\
\hline $\begin{array}{c}\text { Industry of } \\
\text { children's goods }\end{array}$ & 0.99 & 13.8 & 0.7 & 14.5 & 1.0 & 1.05 \\
\hline
\end{tabular}

Efficiency of state support in some industries is at the maximum permissible level, in transport mechanical engineering as well as in timber processing complex the efficiency is less than 1.

\section{Discussion}

Thus, it is possible to claim that the problem of low effectiveness of the use of state support in the systemically important organizations and institutes of development is connected with actually estimate order of financing. With respect thereto the transition from the estimate financing to the project financing is necessary [3-6].

In the conditions of the budget restrictions it is necessary to develop the project format of implementation of state programmes providing detailed study not only mechanisms of the programme but also forecasting of the development of receivers of the support.

The project format is urgent for federal programmes, but even more for regional programmes which budgets are extremely limited. The project format allows to expand the range of sources of financing, including at the expense of means of community [7-9].

The project format of the implementation of state programmes assumes a certain sequence of actions (Figure 4).



Fig. 4. Algorithm of the design format of implementation of the public project.

At the last stage it is necessary to use the internationally acknowledged system of the efficiency evaluation of budget expenses (Figure 5). The European experience, which has been tested over several years after the crisis of 2008, provides a clear framework for thinking about spending proposals and the structured process for appraising, developing 
and planning to deliver the best public value. All of which is captured through the well prepared business case which supports evidence based decisions [10-12].

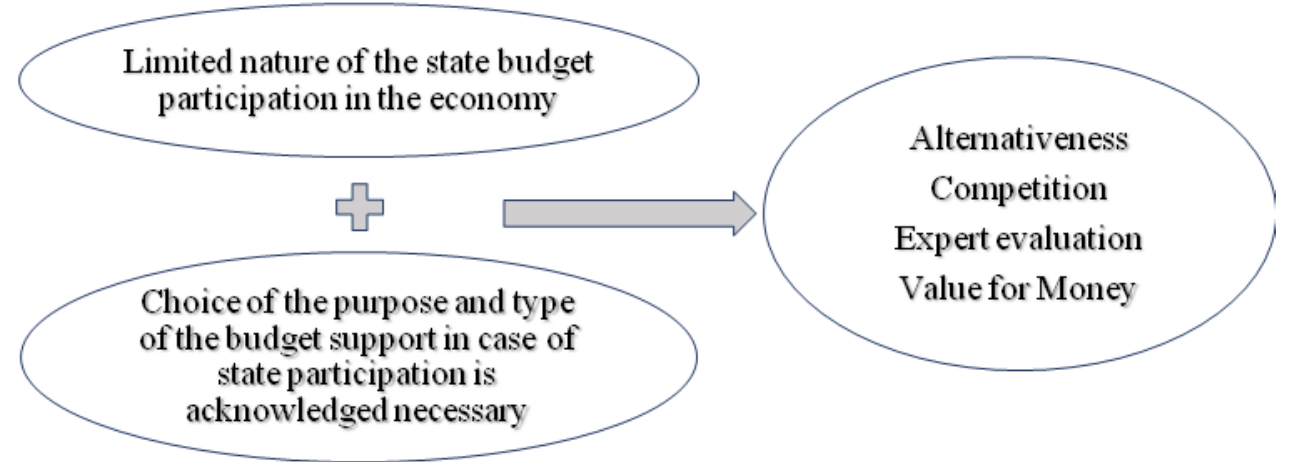

Fig. 5. Crucial elements of internationally acknowledged system of the increase in the efficiency of budget expenses basing on the project approach.

The set of legislative requirements to the order of the choice of the purpose of implementation of the measures of governmental (municipal) programmes should include [13-15]:

- the availability of specific quantitatively or qualitatively measurable economic effect, used as the main criterion in case of the efficiency evaluation of implementation of a measure, as well as accurately certain term during which such result is to be obtained;

- the final result is provided by the optimum form of interaction with individuals and by the use of private investments;

- the compliance of the final result to the documents of the state strategic planning $[16,17]$.

\section{Conclusions}

Thus, it will be only possible to make the decision on the budgetary funds allocation on the basis of alternative approach (project approach), taking into account the competitive advantages, the expert evaluation of cash flow, comparison of the products surplus provided by the state support with the amount of the state support itself.

For the increase in the efficiency of budget expenses, the infrastructure development should become the priority of the budget policy, including: support of the infrastructure of agrarian and industrial complex, innovative infrastructure, institutes of development. The main tools of such a policy are the following:

- CIP (complex investment project),

- TIF (Tax Increment Financing),

- SIP (special investment project).

The special attention is to be paid to the complex of the interconnected investment projects, including projects of the creation new or upgrades of the existing enterprises of various patterns of ownership, as well as the projects of creation of industrial, innovative necessary infrastructure, which construction requires the main manager of federal budget funds to reconsider the budgetary appropriations of the federal budget in the next financial year or in the planning period $[18,19]$.

Such a complex can include the projects: 
- of creation of industrial parks and science and technology parks (industrial science and technology parks and science-and-technology parks in the sphere of high technologies),

- special economic zones,

- innovative territorial clusters,

- territories of the advancing social-and-economic development,

- infrastructures in monotowns.

Prospects of such a budget policy suppose the following:

- development of perspective instruments of the increase in the high-technology and innovative component of the Russian economy,

- transition from estimate financing to project financing,

- creation of the unified register of infrastructure projects,

- forming of a new system of the efficiency evaluation of budget investments.

\section{References}

1. The Green Book. Appraisal and Evaluation in Central Government. Treasury Guidance (TSO, London, 2011)

2. Industry policy of the state support of the enterprises of real and financial sectors of the economy (Ministry of Finance of the Russian Federation, Moscow, 2016)

3. N.G. Verstina, E.M. Akimova, T.N. Kisel, N.N. Taskaeva, Asian Social Science 11(14), 169-180 (2015)

4. N.G. Verstina, T.N. Kisel, N.N. Taskaeva, E.Y. Chibisova, Life Science Journal 11(8), 326-330 (2014)

5. A.B. Mottaeva, As.B. Mottaeva, International Journal of Applied Engineering Research 10, 43446-43449 (2015)

6. A.B. Mottaeva, As.B. Mottaeva, International Journal of Applied Engineering Research 11, 6808-6816 (2016)

7. I. Polyakova, E. Vasilyeva, Procedia Engineering 165, 1380-1387 (2016)

8. I.S. Polyakova, The MSUCE Bulletin 6, 86-89 (2011)

9. I.S. Polyakova, E.Yu. Chibisova, Journal of economy and entrepreneurship 5 (70), 579-582 (2016)

10. J. Flanagan, P. Nicholls, Public Sector Business Cases using the Five Case Model: a Toolkit (Crown, London, 2016)

11. J. Lowe, Public sector business cases using the five case model (HM Treasury, London, 2013)

12. V.V. Okrepilov, V.L. Makarov, A.R. Bakhtizin, S.N. Kuzmina, Economy of Region, 2, 301-313. (2015) DOI: 10.17059/2015-2-24

13. S. Bovteev, S. Kanyukova, V. Okrepilov, A. Rezvaia, Journal of Applied Engineering Science, 14 (1), 121-127 (2016)

14. N.G. Verstina, E.M. Akimova, T.N. Kisel, E.Y. Chibisova, V.A. Lukinov, International Journal of Economics and Financial Issues 5 (3S), 217-223 (2015)

15. N.G. Verstina, N.N. Taskaeva, T.N. Kissel, E.M. Akimova, A.V. Fedosina, International Journal of Applied Engineering Research 10 (20), 41156 - 41163 (2015)

16. E.M. Akimova, D.V. Knyazev, International Journal of Applied Engineering 10, 18 (2015)

17. E. Stein, N. Taskaeva, E. Chibisova, Procedia Engineering 165, 1410-1416 (2016) 
18. N.I.Vatin, D.V.Nemova, D.S.Tarasova, A.A.Staritcyna, Advanced Materials Research, 953-954, 854-870, (2014), DOI 10.4028/www.scientific.net/AMR.953954.854

19. D. Vuksanovic, Y. Nikitin, V. Murgul, N. Vatin, V. Pukhkal, Applied Mechanics and Materials, 680, 499-503 (2014) 